\title{
Anti-angiogenese, een briljant concept in de oncologie
}

Citation for published version (APA):

Griffioen, A. W. (2006). Anti-angiogenese, een briljant concept in de oncologie. Maastricht University. https://doi.org/10.26481/spe.20060915ag

Document status and date:

Published: 15/09/2006

DOI:

10.26481/spe.20060915ag

Document Version:

Publisher's PDF, also known as Version of record

\section{Please check the document version of this publication:}

- A submitted manuscript is the version of the article upon submission and before peer-review. There can be important differences between the submitted version and the official published version of record.

People interested in the research are advised to contact the author for the final version of the publication, or visit the DOI to the publisher's website.

- The final author version and the galley proof are versions of the publication after peer review.

- The final published version features the final layout of the paper including the volume, issue and page numbers.

Link to publication

\footnotetext{
General rights rights.

- You may freely distribute the URL identifying the publication in the public portal. please follow below link for the End User Agreement:

www.umlib.nl/taverne-license

Take down policy

If you believe that this document breaches copyright please contact us at:

repository@maastrichtuniversity.nl

providing details and we will investigate your claim.
}

Copyright and moral rights for the publications made accessible in the public portal are retained by the authors and/or other copyright owners and it is a condition of accessing publications that users recognise and abide by the legal requirements associated with these

- Users may download and print one copy of any publication from the public portal for the purpose of private study or research.

- You may not further distribute the material or use it for any profit-making activity or commercial gain

If the publication is distributed under the terms of Article $25 \mathrm{fa}$ of the Dutch Copyright Act, indicated by the "Taverne" license above, 
Anti-angiogenese, een briljant concept in de oncologie 


\section{Colofon}

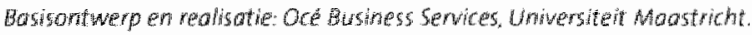

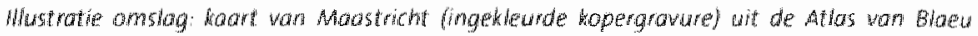
'Toonned der steden' 1652 .

158N90-5687-245.9

NUPR 870

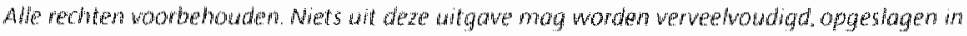

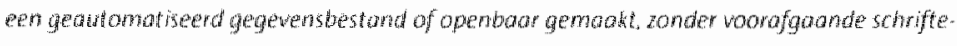




\section{Anti-angiogenese, een briljant concept in de oncologie}

Rede

uitgesproken bij de anvaarding wan het ambt wan bijzonder hoogleraar Experimentele Oncologie en Angiogenese aan de flaculteit der Geneeskunde van de Universiteit Maastricht

op vrijdag 15 september 2006

door

Dr. Arjan W. Griffioen

1)

4 Uniwersitelit Mastricht 


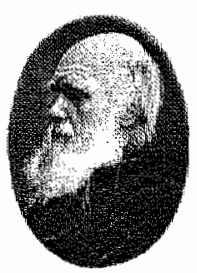

"In the long history of humankind (and animal kind, too) those who learned to collaborate and improvise most effectively have prevailed"

Charles Robert Darwin (1809-1882) 
Mijnheer de Rector Magnificus, geachte toehoorders,

\section{Inleiding}

vandaag zal ik officieel het ambt aanvarden van hoogleraar $k$ zal dat doen met het aan $u$ woorstellen van min vakgebied, de Experimentele Oncologie, in het bijzonder de Angiogenese.

Het is exact 25 jaar geleden dat ik begon met de studie biologie aan de Vrije Universiteit in Amsterdam. Na een keuze voor de medisch biologische richting, heeft zich snel de rode draad afgetekend waarlangs mijn wetenschappelijke carriere zich heeft begeven. Deze rode draad valt te omschrijven als "cel-activatie". In eerste instantie. gedurende mijn promotieperiode, betrof dat een belangrijk proces van het immuunsysteem, namelijk de activatie van $B$ lymfocyten. Na het verkrijgen van mijn doctoraat, vandaag precies 15 jaar geleden, heeft de rode draad zich voortgezet via een post-doc project met als onderwerp de activatie van tumorcelien. Het vakgebied van de angiogenese werd door mij betreden in 1994. waama het onderzoek naar de activatie van endotheelcellen, dat zijn de cellen die de binnenbekleding van alle bloedvaten vormen, het centrale onderwerp vormde van mijn wetenschappelijke activiteiten. Dit zal uit het verdere verloop van mijn rede duidelijk worden.

Hoewel angiogenese een breed onderzoeksthema is dat in vele facetten van de biologie en daarom ook bij vele ziektebeelden een rol speelt, verraadt de titel van deze rede dat het vandaag met mame over oncologie zal gaan, het vakgebied dat mijn grootste interesse heeft. Ik zal uitleggen wat angiogenese is en hoe interventie in angiogenese gebruikt kan worden bij de behandeling van ziekten, wat daarbij de problemen zijn en hoe die opgelost kunnen worden.

\section{Introductie in de angiogenese}

Angiogenese is de vorming of aanleg van nleuwe bloedvaten. Voor de groei van nieuw weefsel is aanwoer van zuurstof en woedingsstoffen en afvoer vam afvalstoffen noodzakelijk. Om dit efficient te laten platsvinden worden daarvoor nieuwe bloedvaten angelegd. Dit gebeurt bij normale fysiologische processen zoals wondgenezing, ovulatie, en bij.woorbeeld lichaamsgroei van embryo tot wolwassen individu. Maar ook is aanleg van nieuwe bloedvaten een kenmerk van vele pathologische processen en ziekten zoals reuma, aderverkalking of atherosclerose, endometriose, vetzucht, blindheid bij suikerziekte, en kanker (1, 2).

Bij de aanleg wan een nieuw bloedwat spelen de endotheelcellen een 
cruciale rol. De eerste stap in het proces van angiogenese is dat de cellen van het groelende weetsel, bijwoorbeeld de cellen van een kankergezwel, valk door een gebrek aan zuurstof, angiogene groeifactoren produceren en in de omgeving uitscheiden. In de buurt gelegen endotheelcellen van reeds bestaande bloedvaten raken hierdoor geactiveerd, warna een reeks van achtereenvolgende stappen plastsvindt (Figuur 1).
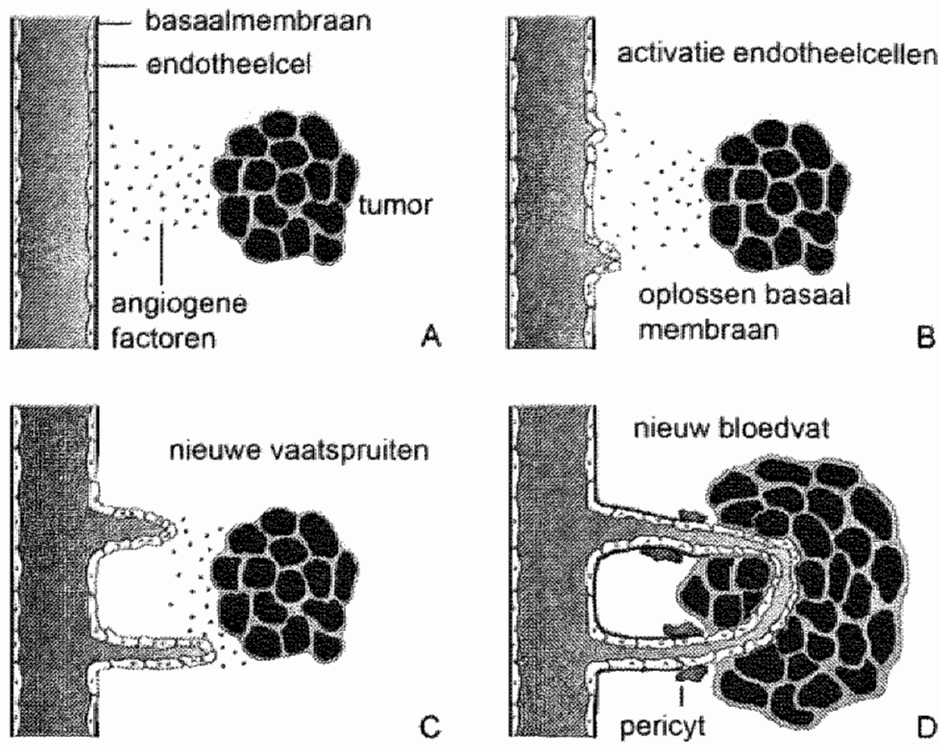

Figuur 3. De verschillende stappen van de angiogenese cascade. A. Productie wan angiogene factoren door bijvoorbeeld een groelende twmor. B. Oplossen van de basalmembralan ert omliggende matrix. C. Migratie en vermeniguddiging van endotheelcellen. Vorming var een nieuwe valatspruit. D. Vorming van een nieuw basala membra an en matrix. Attractie van steuncellen (pericytern). Nieurwe bloedcirculiatie.

Allereerst gaan de endotheelcellen speciale enzymen produceren die het omliggende weefsel, zoals de basaalmembraan en de om thet bloedvat gelegen extracellulaire matrix, zacht maken. Op deze manier wordt de migratie van endotheelcellen in de richting van de groeistimu. lus mogelijk. vervolgens zullen de endotheelcellen zich vermenigvul. digen zodat voldoende nieuwe cellen voorhanden zijn on een nieuwe vatspruit te ontwikkelen. Deze zal na polarisatie en differentiatie van de endotheelcellen een prematuur bloedvat wormen dat bloed kan ver. 
woeren. In dit wroege ontwikkelingsstadium zijn de nieuwe bloedvaten weinig functioneel en vindt er op grote schaal lekkage plats. Eerst na de vorming wan een nieuwe laag van matrix en het aantrekken van steuncellen (pericyten) en gladde spiercellen is er sprake van een functioneel nieuw bloedvat. Dit hele proces is nauwkeurig gereguleerd, waarbij een veelheid aan werschillende typen cellen betrokken is, en staat onder positieve regulatie van vele angiogene groeifactoren, zoals vasculair endothee groeifactor, afgekort als VEGF, Ook vindt regulatie plaats door endogene moleculen die dit proces kunnen remmen (Figuur 2)(3).

UIT

AAN
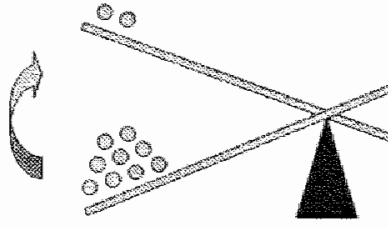

Stimulatoren

wasculair endotheel groeffactior (VEGF) fibroblas: groestactor (FGF) plazties factor 4 interferon-allia angliastatine endostatine

Figuur 2. Het weegschaal model. Angiogenese wordt gereguleerd door positheve en negatheve signalen. Angiogenese kan worden gestimuleerd door toename wan stimulatoren of door afname van remmers (3).

\section{De ontwikkeling van een onderzoeksveld}

Angiogenese kwam wereldwijd in de belangstelling toen in het begin van de jaren ' 70 , dus zo'n 35 jaar geleden, door een onderzoeker in Boston, genaamd Judah Folkman, werd gehypothetiseerd dat in patien. ten met kanker, tumoren het meest kwetsbaar zijn op het nivo van de bloedvaten. Met andere woorden, tumorgroei is athankelijk van angiogenese. Hieruit volgend hypothetiseerde hij dat wanneer het mogelijk zou zijn bloedvatgroei af te remmen, of zelfs stil te leggen, dit een mogelijkheid zou bieden voor de behandeling van kanker. Het is interessant te bedenken dat een zo vanzelfsprekende gedachtegang pas zo recent tot ontwikkeling is gekomen en is doorzien als toepassing woor de behandeling van ziekten. Een werklaring hiervoor is dat dit wooruitstrevende idee werd geboren in een tijdperk, de jaren 1960 en "70, waarin de bioweten- 
schap weliswaar sterk in ontwikkeling was, maar die, wergeleken met het huidige niweau van ontwikkeling: nog in de kinderschoenen stond. In het boek 'Doctor Folkman's war; new hope for cancer sufferers" wordt beschreven hoe in de jaren' '5o en "6o gestoeid werd met basale biochemische en biologische technieken, zoals de isolatie van groeifactoren uit serum wan patiënten en het buiten het lichaam kweken van cellen, technieken die een beginnend onderzoeker tegenwoordig binnen een paar dagen onder de knie heeft. Een van de belangrijkste hordes die genomen diende te worden, en voor het onderzok naar angiogenese noodzakelijk was, was de mogelijkheid on endotheelcellen buiten het lichaam tot celdeling aan te zetten. Wereldwijd werd op dat moment aangenomen dat endotheelcellen buiten het lichaam niet gekweekt konden worden. Dat dit als dogma werd alamaard blijkt wit het feit dat zelfs de eerste publicatie van gekweekte endotheelcellen, gepubliceerd door een Japanse onderzoeksgroep midden jaren "6o, wegens gebrek aan een aannemelijke verklaring als wetenschappeiljke zwakte werd afgedaan.

Al deze moeilijkheden leidden ertoe dat Folkman's idee, dat bloed. vatgroei specifiek geremd kon worden, en dat toepassing daarvan een mogelijkheid zou bieden bij de behandeling wan kanker, door niemand serieus werd genomen en zelfs ronduit werd geridiculiseerd. Dat is over het algeneen niet een makkelijke situatie om te werken aan nieuwe ideeèn. Folkman echter, gaf niet op en zette zijn gloedvolle carriere als chirurg aan de kant en begon een lange wetenschappelije zoektocht naar de uitwerking wan een veelbelovend idee. Pas in 1974 lukte het zijn onderzoeksgroep voor het eerst geilsoleerde endotheelcellen in een kweekfles tot vermenigwuldiging aan te zetten, door aan de kweek bloedserum of - plasma toe te voegen. Dit was een ware wetenschappelijke doorbraak, en leidde tot de ontdekking van stoffen in het serum met angiogenese stimulerende activiteit, zoals moleculen die we nu fibroblast groeifactor (FGF) en VEGF noemen. Nu het mogelijk was om endotheelcellen te kweken buiten het licham, was het de grote uitdaging om manieren te vinden endotheelcelgroei juist te remmen. Omdat het allemaal pionierswerk was verliep dit onderzoek waag. Echter na een periode van ruim 15 jaar, a an het begin van de jaren ' 80 , werden toch de eerste stoffen beschreven die een remmende werking op de groei van endotheelcellen bleken te hebben. De eerste moleculen met dit effect waren interferon-alfa en een stof die zich bevindt in bloedplat. jes, genaamd plaatjes factor-4. Later, in 1990, werd in het laboratorium van folkman bij toeval het schimmel-antibioticum fumagilline ontdekt. 
dat ook in proefdiermodellen tumorgroei kon remmen. En tussen 1994. en 1997 werden de moleculen angiostatine en endostatine geboren en beschreven in de wetenschappelijke toptijdschriften Cell en Nature, als een soort validatie van het concept dat remming van angiogenese mogelijk is en een toepassing kan hebben bij de behandeling van kanker (4.5). Dit onderzoek sloeg in als een bom, want het vergde van niemand veel kennis en woorstellingsvermogen om zich te realiseren dat deze middelen wel eens het einde van het tijdperk van kanker konden inluiden.

Wereldwijd hebben deze publicaties geleid tot een explosie aan nieuwe onderzoeksprojecten en pogingen om angiogeneseremmers te ontdekken en te ontwikkelen voor toepassing in de therapie bij mensen. Die explosieve aandacht is altijd goed te illustreren aan de hand van het aantal publicaties over VEGF, dat er over heel het jaar 1990 ongeveer 10 waren, terwijl dat er tegenwoordig ongeveer 10 per dag zijn. Ook wij in het Angiogenese Laboratorium in Maastricht hebben deelgenomen aan deze wedstrijd en een 5 -tal angiogeneseremmers ontdekt en beschrevern.

\section{Een briljant concept in de oncologie}

In de titel wan deze rede gebruik ik het woord briljant in de betekenis van glansrijk en virtuoos. I zal uitleggen waarom anti*angiogenese een briljant concept is. Ik hoef u niet uit te leggen dat de behandeling varu kanker nog veel te wensen overlat. Wanneer we het positief stellen, dan leidt de voortschrijding van de ontwikkeling van kankertherapie tot een verlaging van de kans op overlijden met ongeveer $1 \%$ per jaar. Wanneer men zich realiseert dat deze verbeteringen hoofdzakelijk te herleiden zijn tot verbetering van voorlichting en preventie, is te begrijpen dat de ontwikkeling van een succesvolle behandeling van kanker, zeker in die gewallen in welke uitzaaingen aanwezig zijn, nog steeds een lange weg. te gaan heeft

De kankertherapie gaat dus gebukt onder grote nog niet opgeloste problemen. Ik zal hiervan de belangrijkste voorbeelden geven. Nast chirurgie en bestraling, behandelingswormen die alleen toepasbaar aljn voor zichtbare tumoren, is op dit moment de meest toegepaste worm van therapie de chemotherapie. Er kleven grote nadelen aan deze vorm van therapie. Chemotherapeutica zijn middelen die in het hele lichaam de celdeling remmen en daardoor veel bijwerkingen kennen, zoals misselijkheid en haaruitval. Een ander groot nadeel wan chemotheraple is dat tumorcellen, vanwege hun genetische instabiliteit en daardoor hun veranderlijkheid, zich kunnen aanpassen a an het geneesmiddel wat er 
toe leidt dat na verloop wan tijd een effectieve therapie onwerkzaam wordt. Dit proces noemen we resistentieontwikkeling. Voorts moel geveesd worden dat chemotherapeutica uitontwikkeld zijn. De afgelopen 20 jaar zijn geen echte doorbraken meer geboekt in de verbetering van deze geneesmiddelen.

Al met al bestaat er dus een schreeuwende behoefte a an nieuwe vormen van therapie die deze nadelen niet kennen. Anti-angiogenese is zo een theraple. $\mathrm{k}$ zal hier een opsomming van de voordelen geen en begin bijde belangrijkste. (1) Een remmervan angiogenese is niet toxisch omdat het uitsluitend groeiende endotheelcellen aanpakt, zoals die in een volwassen kankerpatient eigenlijk uitsluitend aanwezig zijn in de tumor. Bijwerkingen zijn dus niet te verwachten. (II) Omdat endotheelicellen genetisch stabiel ziln, zal er geen resistentie ontwikkeld worden, zodat een effectieve therapie langdurig werkaam blifft. (IIt) Anti-angiogenese richt zich op de endotheelcellen, en die bevinden zich in direct contact met het bloed. Het probleem van de moeilijke doordringbaarheid van het tumorweefsel, dat woor chemotherapie beperkingen oplegt, doet zich bil anti-angiogenese therapie niet voor. (IV) Endotheelcellen zullen wellicht overal in het lichaam dezelfde eigenschappen hebben, zodat: een effectieve therapie bruikbaar is woor meerdere, zo niet alle, varmen vam kanker. Dit laatste voordeel is goed woorstelbaar als men dit afzet tegen het feit dat er meer dan 100 verschillende vormen van kanker bestaan, alle met specifieke genetische en biologische eigenschappen. En als laatste, (V) omdat veel tumor cellen afhankelijk zijn van één enkel bloedvat, zal het doden van elke endatheelcel de sterfte van gemiddeld 50-100 tumorcellen tot gevolg hebben.

Alhoewel men zich moet realiseren dat sommige wan de hiervoor genoemde voordelen van anti-angiogenese louter theoretisch van aard zijn en dus in de praktijk nog bewezen zullen moeten worden, staat niets de ideale strategie van kankertherapie meer in de weg. Met andere woorden, een therapie die uitsluitend woordelen biedt, een briljant concept.

\section{Geloof, hoop en James Watson}

Om voorlopig deze positieve visie aan te houden, is een kleine anekdote hier op zijn plaats. Enkele jaren geleden werd ik door Dr. Folkman uitgenodigd woor een bijeenkomst van enkele dagen in het Cold Spring Harbor Laboratory in de staat New York, om met zon 20 andere onderzoekers de toekomst van de angiogenese te bespreken. In dit instituut is tevens. Dr. James Watson werkzaam. Hij won in 1962: samen met zijn collega's Francis Crick en Maurice Wilkins, de Nobelprijs 
voor de Geneeskunde voor de ontmanteling van de structuur van DNA en de betekenis voor de erfelijkheid van levende organismen (6). Uit de boeken wan zijn hand wist ik dat James Watson een groot bewonderaar is wan Charles Darwin. omdat deze zonder de kennis van nu over hoe erfelljkheid ligt opgesloten in de kern van alle cellen, toch via de kunst van het observeren, de evolutietheorie heeft opgesteld en zodoende de maatschappij grondig heeft veranderd.

Tot mijn verbazing was James Watson deelnemer aan deze bijeenkomst. Tijdens een diner zat ik naast hem en vroeg ik hem waarom hij zo geinteresseerd was in angiogenese. Hij antwoordde dat hij een bewonderaar was van Judah Folkman en eerder noemde hij hem de Charles Darwin wan de zoe eeuw. Hij vertelde dat Folkman's idee, om niet de tumorcellen maar de endotheelcellen a an te pakken, hem erg aansprak. 'Want', zei hij: 'als anti-angiogenese niet een doorbraak in de therapie van kanker gaat worden, dan gaat voorlopig niets dat worden, om reden dat de genetica van tumorcellen veel te gecompliceerd is om daar ooit een vinger achter te krijgen. Voor mij was dat een geweldige opsteker, en ik denk ook voor anderen. Het lijkt me daarom goed deze persoontijke communicatie met éen van de top-wetenschappers van de $20^{e}$ eeuw bij dezen, in het kader van mijn inauguratie, te publiceren.

\section{Is er een doorbraak in zicht?}

$\mathrm{Na}$ al deze loftuitingen en anprijzingen is de vraag gerechtvaardigd. waarom dit briljante concept van angiogeneseremming nog niet geleid heeft tot de zo gewenste doorbraak in de therapie van kanker. Of zelfs, is er wel een doorbraak in zicht? Toegegeven, het concept heeft zich bewezen in de kliniek met de ontwikkeling van Avastin, een angiogeneseremmer die bij toepassing bij patiënten met dikke darmkanker duidelijk levensverllengend werkt. Maar waarom nog steeds geen volledige genezingen? Hiervoor zijn enkele redenen aan te geven. Om te beginnen valt het vakgebied van de antiangiogenese te omschrijven als nieuw. Als de vergelijking getrokken wordt met de ontwikkeling van de chemotherapie, waar nu zo'n 70 jaar erwaring mee is, mag mijns inziens niet verwacht worden dat binnen 10 jaar na de eerste ervaringen met angiogeneseremmers in de kliniek, de mogelijkheid tot genezing van kanker birnen handbereik ligt. Ook wanneer we de vergelijking met andere vormen van kankertherapie aangaan, zoals immuno-en radiotherapie, is anti-angiogenese een relatief nieuw veld van onderzoek. Verder is het mijn persoonlijke overtuiging dat er voor sommige angiogeneserem. mers, in de hype van enkele jaren terug, de fout is gemaakt van een te 
snelle ontwikkeling naar klinische studies. Hierdoor hebben middelen als endostatine in de kliniek tot nu toe gefald. Het is goed dat China, een land dat onafhankelijk werkt van de Amerikaanse food and Drug Administration, endostatine zeer recent wel commercieel verkrijgbaar heeft gemaakt. Er wordt algemeen reikhaizend uitgekeken naar de pesultaten wan patiêntenstudies aldaar op langere termijn.

\section{Nalar de ontwikkeling van een nieuwe therapie voor kanker}

Nu steeds duideliker wordt wat de problemen in het veld zijn, zal ik in het komende deel wan deze lezing toelichten war ik denk dat de weg ligt naar de ontwikkeling van nieuwe effectieve angiogeneseremmers die bruikbaar zijn in de kliniek. Geneesmiddelontwikkeling begint vaak met onderzoek aan de mechanismen wan een proces. Daarna vindt identificatie van doelwiteiwitten en het ontwerp van een molecuul plaats dat zou kunnen dienen als geneesmiddel. Na een verbeterproces wordt een potentieel geneesmiddel eerst in vitro en daana in proefdieren uitgetest. Verwolgens moeten kinetiek- en toxiciteitsstudies en stabiliteitsbepalingen gedaan worden alvorens een middel bij mensen mag worden getest in fase 1 , II en 111 klinische trials. Klinische studies zijn meestal het domein wan de grote farmaceutische bedrijven. Binnen mijn Angiogenese Laboratorium (7) hier in Maastricht, wordt wooral een bij. drage geleverd aan de vroege stappen van geneesmiddelontwikkeling. zoals uit de wolgende presentatie van de verschillende onderzoekslijnen zal blijken.

7.

Alereerst is het noodzakelijk inzicht te hebben in hoe de groei van endotheelcellen is gereguleerd. Wij hebben er daarom voor gekozen, via een moleculair biologische benadering, het genexpressieprofiel van endotheelcellen in een tumor te vergelijken met dat van endotheelcellen in gezond weefsel. Dit onderzoek, dat wordt uitgevoerd onder leiding van Dr. Judy van Beijnum, heeft aangetoond dat een 17 -tal genen verhoogd tot expressie komen in de bloedwaten van de tumor. Een aantal van deze genen, waaronder een gen genaamd High Mobility Group Box-1 en vimentine, zijn bruikbaar gebleken als doelwitmolecuul, of in vaktermen als target. om een anti-kankertherapie tegen te richten. Wanneer proefdieren met kanker worden behandeld met antilichamen gericht tegen deze moleculen, blijkt angiogenese geremd te worden en de groel van tumoren belangrijk verminderd en in sommige gevallen zelfs wolledig geblokkeerd (8). Het is dan ook de eerste doelstelling van het 
onderzoek in het Angiogenese Laboratorium om deze antilichamen, of andere moleculen met dezelfde werking, verder te ontwikkelen in proefdiermodellen voor toepassing bij de mens. De succesvolle introductie de afgelopen jaren van op antilichamen gebaseerde geneesmiddelen, zoals Herceptin voor de behandeling van borstkanker, Rituximab voor non-Hodgkin lymfoom en Avastin woor dikke darmkanker, stemt hierbij hoopvol.

\section{2.}

Een andere strategie die gekozen is voor de ontwikkeling van nieuwe therapieen tegen kanker op basis van anti-angiogenese, is het ontwerpen wan nieuwe biologisch actieve stoffen. Dit onderzoek, dat in belangrijke mate gefinancierd wordt door de Nederlandse Organisatie voor Wetenschappelijk Onderzoek (NWO), wordt uitgevoerd in samenwerking met Prof. Kevin Mayo van de Universiteit van Minnesota in Minneapolis, Verenigde Staten. In mijn laboratorium staat dit onderzoek onder leiding van Dr. Victor Thijssen. De aanpak van dit onderzoek is het ontwerpen van nieuwe angiogeneseremmers op basis van het samenbrengen van de structuur en de eigenschappen wan in het lichaam woorkomende angiogenese remmende moleculen. Dit onderzoek heeft de afgelopen jaren geleid tot de ontwikkeling van anginex (9). Dit niet-natuurlijke eiwit remt angiogenese door de inductie van geprogrammeerde celdood in geactiveerde endotheelcellen zoals die voorkomen in tumoren. Dit werkingsmechanisme leidt rechtstreeks tot stagnatie van tumorgroel en dat hebben we de afgelopen jaren in een veelheid aan proetdiermodellen aangetoond (10).

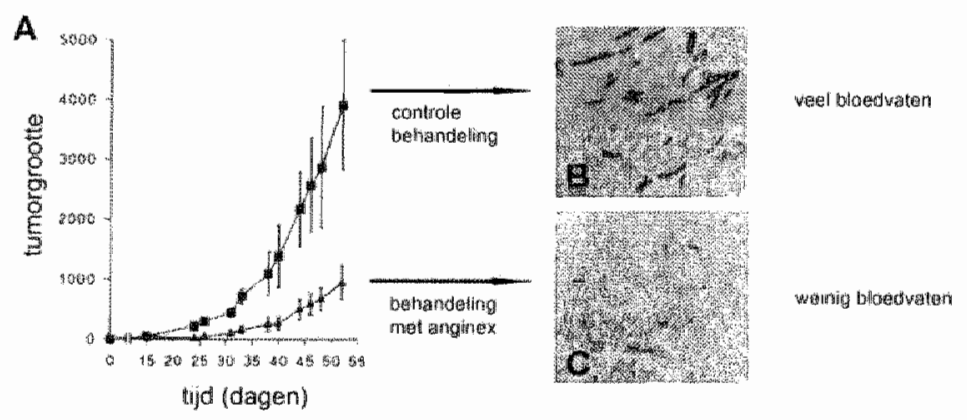

Figuu 3. Anginex remt tumargraei in mulden (A) Het werkingsmechanisme as gebaseerd op rerming van bloed vatgroei zoals in $B$ en $C$ te zien is. 
Anginex is het belangrijkste product van het Argiogenese Laboratorium. Enkele klinische centra in Europa en de Verenigde Staten staan klaar om het bij mensen met kanker te testen. Dit is afhankelijk wan het bijeenbrengen van woldoende financiele middelen. Veel grote farmaceutische industrieen zijn echter huiverig voor het ontwikkelen van eiwitten als geneesmiddel, vanwege de verwachte gemakkelijke afbraak in het lichaam. Veel meer belangstelling bestaat voor kleine organisch-chemische moleculen als geneesmiddel. Mijns inziens is dit niet terecht omdat de afbraak van een eiwit sterk afhangt van de structur van het eiwit. Het mogelijke nadeel van snelle afbraak wordt echter ruimschoots goedgemaakt door het enorme voordeel van de afwezigheid van toxiciteit wan eiwitten. Het falen van een eiwit-geneesmiddel in de kliniek door gebleken toxiciteit is zeldzaam, terwijl kleine organisch-chemische moleculen alle in meer of mindere mate toxiciteit en bijwerkingen vertonen.

Niettemin hebben we van de Amerikarnse organisatie The National Institutes of Health (NIH) een omvangrijke subsidie gekregen om een klein organisch-chemisch molecuul te ontwikkelen, dat het werkingsw mechanisme van anginex imiteert. Zulke moleculen worden in vaktermen mimetica of gewoon 'small molecules' genoemd. Het ontwerpen wan 'small molecules', en zeker de synthese daarvan, bleek een moeilijke en technische aangelegenheid waarvoor we kennis hebben moeten halen uit verschillende hoeken van de wetenschap, en waar we een multidisciplinaire aanpak van de vakgebieden synthetische chemie, biochemie en biologie hebben moeten aanwenden. Dit was een zeer interessante exercitie die mij soms diep in de spelonken van de chemie dreef, en die mij eens te meer duidelijk maakte dat ik in de biologie op mijo plek zit.

De chemici in Minneapolis ontwierpen het ene na het andere mole. cuul, synthetiseerden het en stuurden het per express naar Mastricht voor het uittesten op gekweekte endotheelcellen. Het was interessant te zlen hoe sommige moleculen geen enkel effect sorteerden, terwijl andere zeer giftig waren en in staat bleken alle levende cellen binnen korte tijd te doden. Na enige tijd definieerden wij een set moleculen met eigenschappen identiek aan die van anginex. De eerste daarvan zijn nu gepubliceerd en zullen verder worden antwikkeld (11). Het is dè verwachting dat deze middelen binnenkort bij mensen met kanker getest zullen worden.

Deze onderzoekslijn levert niet slechts mieuwe geneesmiddelen, 
maar biedt ook gereedschap voor onderzoek naar de mechanismen van anglogenese. De ontdekking van galectine-1 als receptor woor anginex en als ideaal doetwitmolecuul woor anti-angiogenese therapte, is daarvan een voorbeeld (12).

3.

De langstlopende onderzoekslijn van het Angiogenese Laboratorium is die welke de relatie onderzoekt tussen angiogenese en het immutunsysteem. Het is reeds lang bekend dat het immunsysteem een belangrijke rol speelt bij de afweer tegen tumorcellen. De afgelopen decennia is wereldwijd gepoogd het immuunsysteem in stelling te brengen bij de behandeling van kanker. Dit gebeurt bijvoorbeeld door behandeling van patiënten met immuunstimulerende stoffen zoals interferon en interleukine-2. Een andere mogelijkheid is het buiten het lichaam vermenigvuldigen van tumorherkennende leukocyten en deze vervolgens teruggeven aan de patient. Ook zijn er strategieën die gebaseerd zijn op vaccinatie tegen tumorcellen. Al deze verschillende strategieèn blijken, ondanks soms fenomenale resultaten in proefdiermodellen, niet de gewenste anti-tumor werking te hebben bij patiënten. Daar zijn vele verklaringen voor de verzinnen. Wanneer het immuunsysteem verkeerd wordt gestimuleerd treedt er juist tolerantie voor tumorcellen op. Dok kan er inductie optreden van zogenaamde regulatoire Tlymfocyten die de immuunrespons tegen de tumor onderdrukken en is het mogelijk dat de herkenning van tumorcellen niet specifiek genoeg is, waardoor de anti-tumor werking niet voldoende is. Een alternatieve verklaring werd door mij in 1996 beschreven, op dat moment nog in samenwerking met Dr. Gerard Groenewegen wan het Utrecht Medisch Centrum (13). In een tumor worden endotheelcellen blootgesteld ala hoge concentraties van angiogene groeifactoren. Dit leidt tot suppressie van de adhesiemoleculen in de bloedvaten die nodig zijn voor infiltratie van de immuuncellen in het tumorweefsel Met andere woorden, thet proces van angiogenese. warmee de tumor groeimogelijkheden voor zichzelf schept, beschermt hem tevens tegen de afweer door het immuunsysteem. Dit is goed waar te nemen met behulp wan intravitale fluorescentie microscopie. Wanneer leukocyten fluorescent gemaakt worden, kunnen leukocytvatwand interacties bestudeerd worden. Er is dan goed te zien dat in tumorbloedvaten deze interacties bijna niet optreden (i4). Toen dit eenmaal duidelijk werd, was het niet zo moeilijk om de hypothese te verzinnen dat het remmen van angiogenese de tumor wel eens verhoogd gevoelig kon maken voor het immuunsysteem. Met een subsidie van het 
Koningin Wilhelmina fonds (KWF) werd begin 200 een project gestarl om wit te vinden of anti-angiogenese therapie een tumor inderdaad kwetsbaar maakt voor het immuunsysteem. Nu, een paar jaar verder, heeft het project onomstotelijk aangetoond dat deze hypothese kon worden aangenomen. Met andere woorden, zo goed als alle angiogeneseremmers die wij getest hebben, bleken een toename van het aantal witte bloedcellen in de tumor te bewerkstelligen (15). Deze vinding maakt het buitengewoon aannemelijk dat bestaande strategicen van immunotherapie verbeterd kunnen worden wanneer ze worden uitgevoerd in combinatie met angiogeneseremmers. Een woor Maastricht plezierige omstandigheid is dat anginex, en vooral enkele van de small molecules: bij de beste middelen behoren die deze immuunregulatie laten zien. Het ligt daarom in de bedoeling in de nabije toekomst de synergie met immunotherapieprotocollen te laten zien in proefdiermodellen. Combinatietherapie van anti-angiogenese en immunotherapie bij mensen ligt dan in het verschiet.

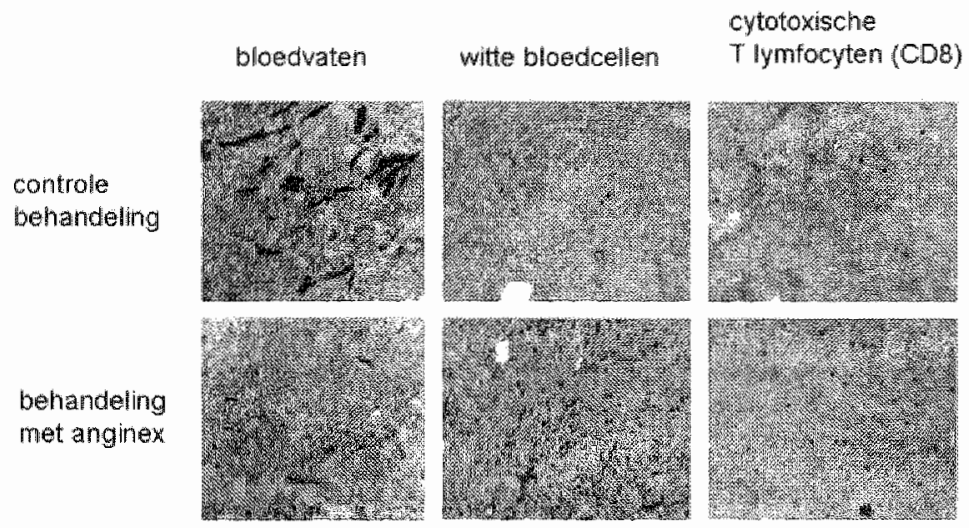

Hguur 4. Immumohistocherniche klleurngen wan tumorweefsel. Behandeling van muizer met tumoren leidt tot minder bloedwaten in de wumor en tot een betere imfiltratie van cellen wan het immususysteern.

Zoals duidelijk wordt, hebben deze onderzoekslijnen van het Anglogenese Laboratorium zowel fundamentele als translationele aspecten. Het zou voor het Research instituut Groei en Ontwikkeling, het onderzoeksinstituut wartoe het Angiogenese Laboratorium 
behoort en dat recent door de Koninkijke Nederlandse Academie voor Wetenschappen is getooid met de status van onderzoeksschool, van onschatbaar belang zijn als ook de verdere klinische ontwikkeling van eigen technologie binnenshuis kan plaatswinden middels het uitwoeren van (fase l) klinische trials. Maastricht heeft geen reputatie op het gebied van fase I studies. Het zou jammer zijn als woor het uiteindelijke bewijs van de kinische toepasbaarheid wan Mastrichtse technologie, gesteund moet worden op expertise elders. Ik signaleer daarom dat hier, met komende hervormingen binnen ziekenhuis en universiteit, krachtig op ingezet moet worden.

4.

Een van de grote voordelen van anti-angiogenese is, zoals reeds eerder gezegd, dat door de genetische stabiliteit van endotheelcellen geen resistentie tegen de therapie zal optreden. Resistentie is het grote probleem van chemotherapie. Hoewel sommige chemotherapeutica fantastische anti-kanker middelen zijn, is een succesvolle behandeling bijna altijd van tijdelijke aard omdat de tumorcellen zich aanpassen en resistentie ontwikkelen tegen het geneesmiddel. Dat endotheelcellen dit niet zullen doen is een theoretische redenering en in het werleden zijn inderdaad enkele studies gedaan met proefdieren die deze theorie bevestigen. Maar, met het voorschrijdend inzicht wordt hier tegenwoordig aan getwijfeld. Een anti-angiogenese therapie die is gebaseerd op het wegvangen van groeifactoren zoals VEGF, zou kunnem leiden tot resistentie doordat de tumorcellen die andere factoren maken dan VECF, hierdoor een groeivoordeel krijgen. Daarnaast zijn er onderzoeksgroepen die nu twiffelen aan de genetische stabiliteit van endotheelcellen in de tumor en genetische afwijkingen hebben aangetoond (16). Hiermee wordt de afwezigheid van resistentieontwikkeling in endotheelcellen op zijn minst ter discussie gesteld.

Deze discussie introduceert de viende onderzoekslijn wan het Angiogenese Laboratorium. Een nieuwe vinding toonde zeer recent aan dat anti-angiogenese wel clegeligk resistentie kan induceren via het fenomeen wan 'vasculaire mimicry. Mimicry is een biologisch principe waarbij planten of dieren hun verschijningsworm aanpassen waardoor ze voor de levensstrijd beter toegerust zijn. Welnu, in uitzonderlijke gevallen kumnen tumorcellen en het zijn meestal die welke het meest agressief zinn, zich door hun genetische instabiliteit zo veranderen dat ze in vorm en functie gaan lijken op endotheelcellen. Deze dedifferenti- 
atie heft tot gevolg dat tumorcellen zelf bloedvaten kunnen vormen en zodoende onafhankelijk worden van de aanleg van reguliere bloedvaten. dus onafhankelijk van angiogenese. Dit proces wordt vasculaire mimicry genoemd en kan waargenomen worden in cen kleine groep van patienten met de meest agressieve tumoren. De onafhankelijkheid van angiogenese is een slechte eigenschap en voorspelt een korte overleving van de patient (17, 18)

Het onderzok aan vasculaire mimicry wordt in mijn laboratorium uitgevoerd onder leiding van Dr. Daisy van der Schaft. Zij was de eerste die aantoonde dat vasculaire mimicry bijdragt aan de bloedcirculatie in een tumor (19). Recent heeft $z$ ij a angetoond dat de behandeling van tumordragende proefdieren met angiogeneseremmers leidt tot een toename van agressieve tumorcellen die eigenschappen van endotheelcellen krijgen en zelf bloedvaten vormen. Met andere woorden, de anti-angiogenese behandeling leidt tot een groeivoordeel van de meest agressieve en angiogenese ona fhankelijke tumorcellen.

Deze op zich alarmerende resultaten houden niet het einde in van de belofte dlie anti-angiogenese in zich heeft. Als gezegd, mimicry van bloedvaten door tumorcellen wordt aangetroffen in slechts een klein deel, ongeveer $3.5 \%$, van de patiënten. Maar de gedachte dringt zich op dat in leder geval woor dit deel wan de patienten anti-angiogenese als op zichzelf staande therapie niet een goede therapie kan zijn. Veeleer zal in deze gevallen gedacht moeten worden aan combinatie met conventionele therapieën zoals chemo-, bestralings-, of immunotherapie. Misschien zijn de soms onbegrepen successen van combinatietherapieen met anti-angiogenese, zoals die de laatste jaren veelwuldig in proefdiermodellen gepubliceerd zijn, en die we ook kennen van de anglogeneseremmers die op de markt verkrijgbaar zijn, terug te voeren op dit fenomeen.

\section{Toekomst perspectieven}

Samenvattend kan gesteld worden dat de problemen met reguliere theraple van kanker, zoals de bijwerkingen, het optreden van resistentie en het uitblijven van verbeterde middelen, het hoofd kan worden geboden met de ontwikkeling wan effectieve angiogeneseremmers. Op verschillende niveaus zal het Anglogenese Laboratorium daar een bijdrage aan leveren. Fen goede aanpak van de ontwikkeling van anti-angiogenese therapie zal mijns inziens leiden tot verbetering van de therapie van kanker. Wellicht zal dit ertoe leiden dat kanker in de toekomst een chronische ziekte genoemd kan worden. Hoewel ik de grootste toepas- 
sing zie bij kanker, zal de toekomst van zuke nieuwe therapieen niet beperkt blijven tot het aandachtsgebied van kanker. ook bij atheroscle. rose, reuma en sommige vormen van blindheid $z a l$ anti-anglogenese een mijlpaal in de geneeskunde bijken. 


\section{Dankwoord.}

Aar het einde gekomen van deze rede is het tijd enkele mensen persoonligk te biedanken.

Allereerst mijn eigen promotor en co-promotor.

Hooggeleerde Zegers, beste Ben, ik heb de eerste professionele schreden in het onderzoek gezet in jou w laboratorium. Ik heb het daar machtig naar mijn zin gehad, en niet alleen omdat ik daar Elly heb leren kennen. Je altijd bedachtzame wijze van discussiëren hebben diepe indruk op mij gemaakt en ik hoop dat ik daar wat van heb meegekregen.

Zeergeleerde Rijkers, beste Ger, zonder dat ik me dat toen heb gerealiseerd, ben jij degene die mij leerde een onderzoeksgroep te leiden. Nog steeds vraag ik me geregell af hoe jij dingen zou hebben aangepakt. Enkele van jouw gevleugelde uitspraken krijgen mijn promovendi ook geregeld te horen.

Hooggeleerde Hillen, beste Harry, jij hebt mij naar Maastricht gehaald. Ik ben je daar dankbaar voor. Je woorliefde voor het vakgebied van de angiogenese en je vertrouwen in mijn aampak van het onderzoek waren altijd merkbaar en hebben me gesterkt. lk mis de tijd dat we bijna dagelijks over angiogenese spraken, en ik hoop dat we nog eens in de gelegenheid zijn samen naar een angiogenesecongres te gaan.

Hooggeleerde Daemen, beste Mat, jij bent een bestuurder. Ik heb op dat gebied veel van je geleerd en ben van plan dat nog veel meer te doen.

Hooggeleerde De Haan, beste Jelte, ik heb veel aan je te danken. Ik heb bewondering voor de manier waarop jij ons instituut naar de KNAW erkenning als onderzoeksschool hebt gekregen.

Mijn zeergeleerde postadocs, Daisy van der Schaft, Victor Thijssen, Sebastien Tabruyn en Judy van Beijnum, you are all great scientists. Thank you very much for your continued support. I realize that part of my successes are simply yours. I would like to go on with all of you and your exciting research. This might not be possible for all of you, but in that case you can rely on my support to you in your scientific future.

Mijn geleerde promovendi, Debby, Ricardo, Karolien, Femke, Marcella, en Veerle, jullie hebben de eerste stappen gezet woor een carriere als 
wetenschapplijk onderzoeker in mijn laboratorium. Het doen van promotieonderzoek vereist zoals jullie gezegd is, en gemerkt hebben, voltedige toewijding. Mijn advies is ga niet uitshuitend uit van de zekerheden wan het leven, durf risico's te nemen en durf te dromen want len nu citeer ik) wie met beide benen op de grond bliff staan, komt geen stap wooruit. En dat is een zekerheid in de wetenschap.

Hooggeleerde Mayo, dear Kevin, our 12-year collaboration resulted in over 25 scientific publications. I think that that is unique and I consider our collaboration as one in a million. I hope wholeheartedly that we can carry on and get it even more fruitful.

My other US friends, Brian Jackson and Dan Fagan, l learned a lot from you on how to run a company. I hope that in the near future something will pan out that will make us business-partners for ever.

Pappa en mamma, ik wil jullie beiden danken voor het vertrouwen dat jallie altijd in mij getoond hebben.

Elly en Christian, jullie betekenen alles voor mij.

ik heb gezegd. 


\section{Referenties}

1. Fohman. A. Mrgiogenesis in cancer, vascular, theumatoid and oher disease. Nat Med, 1: 27-31,1995.

2. Griffoen. A. W. and Molerna. G. Angingenesis: potentiafs for pharmacologic intervention in the treatment of cancer, cardiovascular diseases, and chronic inflarimation phamacol Rev, $52: 217 \cdot 268,2000$.

3. Hanahan, D. and Folkman, J Patterns and emerging mechanisms of the angiogenic switch durng tumorgenes $\mathrm{Cell}, 86: 353-364.1996$.

4. OReilly, M. S, Boehm, T, Shing, Y, Fukd, Nasios, G, Lane, W. S. Fynn, E., Birkhead, R. Olsen, B. R. and Folkman, J. Endostatin: an endogenous intibitor of angiogenesis and tumor growth. Cell, 88: 277-285, 1997 .

5. O'Reily, M. S. Holmgren, L, Shing, Y, Chen, C. Rosenthal R. A. Moses, M. Lane, W. 5. Cao, Y. Sage, F. H., and Folkman, J Anglostatin a novel angiogenesis inhi. bitor that mediates the suppression of metastases by a lew 5 lung carcinoma. Cell, 79: $315,328,1994$.

6. Www nobelprize org/nobel prizes/medicine/laureates/1962

7. wwwangiogeneris.n

8. van Beijnum, J. Dings, R. P, wan der Linden, E. Zwaans, B. M. Ramaekers, F. C. Mayo, K. H. and Griffioen, A. W. Cene expression of tumor angiogenesis dissected; spechic targeting of colon cancer angiogenic vasculature. Biood, 2006.

9. Griffioen. A. W, van der Schaft, D. W. Barendsz-Ganson, A. F, Cox, A. Struiker Boudier, H. A., Hillen. H. F. and Mayo, K. H. Anginex a designed peptide that inhibits angiogenesis. Biochem $, 354: 233-242,2001$.

10. van der Schaft, D. W. Dings, R. P. de Lussanet, O G., van Eijk, L.. I. Nap. A. W., Beets-Tari, R. G. Bouma-Ter Stexge, J.C., Wagstaf, J, Mayo. K. H. and Griffioen, A. W. The designer antanglogenic peptice anginex targets tumor endothe. lial cells and inhibits tumor growth in animal models. Faseb J, 16: 1991-1993. 2002 .

n. Dings, R. P. Chen, X, Hellebrekers, D. M. van Eijk, L. I. Zhang. Y., Hoye, T. R. Griffioen. A. W. and Mayo, K. H. Design of nonpeptidic topomimetics of antiangiogenic proteins with antitumor activities J Natl Cancer Inst, $98: 932936$. 2006.

12. Thijssen, V. L. Postel, R, Brandwilk, R. J., Dings, R. P. Nesmelowa, I, Satïn, S. A., Werhofstad, N. Nakabeppu, Y, Baum, L. G., Bakkers, J, Mayo, K. Im., Poirier, F, and Grifioen. A. W. Calectin-1 is essential in anglogenesis and is a larget for antiangiogenesis therapy. Proc Nat Acad. ScIUSA, in press, pending minor revision, 2006.

13. Griftoen, A. W. Damen, C. A. Bliham, G. H, and Groenewegen, C. Tumor angilo. genesis is accompanied by a decreased inflammatory response of tumor. associated endothelum Blood, 88, 66, $673,1996$.

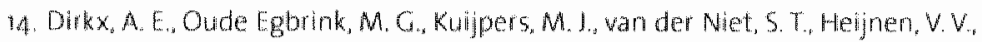
Boumater Steege.J. C., Wagstaff, I. and Griftoen, A. W. Tumor angiogenesis modulates laukocyle vessel wall interactions in vivo by reducing endothelial adhesion molecule expression. Cancer kes, $63: 2322 \sim 2329,2003$. 
15. Dirkx, A. E, oude Egbrink M. G. Castemans, K., van der Schaft, D. W. Thìssen, W. L. Dings, R. P, Kwee, L. Mayo, K. H., Wagstaff, I. Boumater Steege, I C. and Gnffioen. A. W. Anti-angiogenesis therapy can overcome endothellat cell anergy and promote leukocyte-endothelum interactions and infitration in tumors Faseb j, $20: 621-630,2006$.

16. Hida, Kand Kagsbrun, M. A new perspectwe on tumor endothelial cells: unexpected chromosome and centrosome abnomalities Cancer Res.65:2507 2510, 2005.

17. Hendrix, M. J, Seftor. E. A., Hess, A. R., and Seftor, R. E Vasculogenic mimicry and tumour-cell plasticity: lessons from melanoma. Nat Rev Cancer, 3: 4im-4 2 , 2003 .

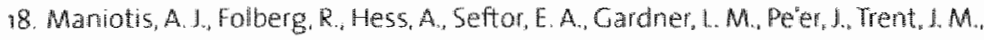
Meltzer, P. S. and Hendrix, M. J. Vascular channel formation by human mela noma cells in who and in vitro: varsculogenic mimicry Am J Pathol, 155:739-752, 1999.

19. wan der Schaft, D. W. Hillen. F, Pawwels, P. Kischmann. D. A. Castermans" K. Egbrink, M. G., Fran, M. G., Sciot, R., Hauben, E., Hogendoon, P. C., Delattre, O. Maxwell. P. H. Hendrix, M. J, and Giffloen, A. W. Tumor cell plasticity in Ewing sarcoma, an altemative circulatory system stimulated by hypoxia. Cancer Res. $65: 11520-11528,2005$ 